\title{
Fostering enabling perceptions of management controls during post-acquisition integration
}

\author{
MARJO VÄISÄNEN, University of Oulu ${ }^{1 *}$ \\ SOPHIE TESSIER, HEC Montréal ${ }^{2}$ \\ JANNE T. JÄRVINEN, University of Oulu ${ }^{1}$ \\ ${ }^{1}$ University of Oulu, Oulu Business School \\ P.O. Box 4600, 90014 Oulu, Finland \\ ${ }^{2}$ HEC Montréal, Department of Accounting Studies \\ 3000, chemin de la Côte-Sainte-Catherine \\ Montréal, H3T 2A7 Canada
}

* Corresponding author, marjo.vaisanen@oulu.fi

Acknowledgements: Accepted by Thomas Ahrens. We acknowledge with thanks the valuable comments and guidance from the editor, Thomas Ahrens, and the two anonymous reviewers. We would also like to thank Martine Cools, Emer Curtis, Sinikka Lepistö and Erik Strauss for additional comments. Earlier drafts of this paper were presented to $10^{\text {th }}$ ENROAC Conference 2015 (Galway), 8 8 $^{\text {th }}$ Conference on Performance Measurement and Management Control 2015 (Nice), MARG/MCA Conference 2015 (Birmingham), 4 ${ }^{\text {th }}$ Association de Contrôle de Gestion workshop 2015 (Trois-Rivières), Emerging Scholars Colloquium at the Telfer School of Management 2015 (Ottawa), 33 ${ }^{\text {rd }}$ EAA Doctoral Colloquium 2017 (Valencia), and to the research seminars in HEC Montréal and Oulu Business School. We would like to thank the participants of these events for their valuable feedback. Marjo Väisänen gratefully acknowledges funding from The Finnish Cultural Foundation, The Foundation for Economic Education, Jenny and Antti Wihuri Foundation, KAUTE Foundation and Tauno Tönning Foundation. 


\title{
Fostering enabling perceptions of management controls during post-acquisition integration
}

\begin{abstract}
The purpose of this paper is to increase our understanding of how enabling perceptions of new management controls (MCs) can be fostered. Prior research suggests that employees are more likely to use new MCs if they perceive them as enabling. However, rapid implementation of new MCs due to circumstances such as mergers and acquisitions can leave employees feeling coerced into using them, making it difficult to foster enabling perceptions. Based on a case study where an acquirer faces pressure to impose rigid controls on an acquired firm, we suggest factors contributing to enabling perceptions. Using interviews, observation and document analysis, we find that positive relationships and mutual trust between the acquirer and the acquiree facilitated enabling perceptions of the MCs. We show that managers at the acquirer actively fostered trust using trust-building activities and communicated their intentions underlying the implementation of new MCs. Doing so helped employees rationalize the controls as tools to help them do their work tasks. We also find that positive relationships reinforced by regular meetings were a way of providing assistance to employees in dealing with rigid MCs. This study contributes to the literature on enabling controls by developing a processual framework that suggests how trust can foster enabling perceptions from the intentions behind the implementation of new MCs, to their development process and daily use. In doing so, the study further develops our understanding of the relationship between enabling control and trust and helps understand how rigid controls can be implemented without generating mistrust.
\end{abstract}

Keywords: Management Control, Management Accounting, Enabling and Coercive, Case Studies, Trust, Mergers \& Acquisitions 


\section{Introduction}

Formalized control systems have received their share of criticism in the past, by having been associated with mechanistic organizations promoting efficiency over flexibility, thus impeding creativity and demotivating employees (Burns and Stalker 1961, Chenhall and Morris 1995). However, Adler and Borys (1996) suggested that top management, by designing formalization as "enabling" instead of "coercive", could facilitate creativity and cultivate positive attitudes in their employees. The main difference in the end result is whether employees perceive formalization as a means to better master their work tasks (enabling), or as a means for management to force them to comply with rules (coercive). As such, a move towards enabling controls is seen as positive (Ahrens and Chapman 2004, Jordan and Messner 2012), because it helps organizations avoid the negative effects of increasing formalization such as dissatisfaction among employees (Adler and Borys 1996), dysfunctional behavior (Adler 2012), and the mistrust of management (Das and Teng 1998, Johansson and Baldvinsdottir 2003).

Ever since Ahrens and Chapman (2004) introduced the concept of enabling control in the management accounting literature, it has gained momentum by providing a theoretical basis for understanding how management controls (MCs) can simultaneously promote flexibility and predictability, as well as centralization and empowerment (e.g. Jørgensen and Messner 2009, Wouters and Wilderom 2008). Employees are more likely to perceive MCs as enabling if they are designed with four features in place. These are repair (being able to fix issues with MCs), internal transparency (understanding the inner workings of the MCs), global transparency (understanding where the MCs fit into global processes), and flexibility (having some discretion over the use of 
the MCs). Enabling perceptions can also be enhanced by involving employees during the design and implementation process of MCs (Wouters and Roijmans 2011, Wouters and Wilderom 2008).

In some situations, however, this might not be feasible. For example, in the case of mergers and acquisitions ( $M \& A)$, it could be difficult to let employees participate in the design of the MCs if these are already established group-wide. As a result, during M\&A integration, MCs are often implemented in a top-down manner (Granlund 2003, Jones 1985). Moreover, companies commonly associated with M\&A are often stock-listed, which means they have to comply with regulatory requirements such as the Sarbanes-Oxley Act (SOX). Under SOX, executives of companies listed in the United States are held accountable for reliable internal controls, record retention, and fraud detection. Thus, executives need to ensure that effective controls are in place. This often manifests itself through behavioral constraints designed to reduce the freedom of choice for employees. We therefore ask the following research question: how can enabling perceptions of MCs be fostered during post-acquisition integration where rigid controls are being imposed upon employees?

This is an important question, because new global MCs often have to compete with old local systems that employees may prefer (Goretzki et al. 2018), and local users are more likely to use the new MCs if they perceive them as enabling (Mahama and Cheng 2013). As Christ (2013, 171) argues, "management and accountants can benefit from understanding the specific aspects of control that cause negative reactions, as well as the conditions that can help mitigate the negative consequences". This is also important at a practical level for top management aiming to implement MCs that help employees, while having to comply with constraints from regulations 
or global systems (Christ 2013, Christ et al. 2012). We therefore argue that a better understanding of the factors that facilitate enabling perceptions of MCs could provide a better theoretical grounding for the functioning of enabling controls.

To address our research question, we turn to the literature on enabling MCs and conclude that although participation and design features can be associated with enabling MCs, they might not represent a comprehensive list, or a definition of enabling MCs. We propose to further explore the role of trust (Adler et al. 1999) and the importance for managers to communicate the intentions behind the implementation of new MCs (Christ 2013). Then, to advance our theoretical development, we draw on a case study that focuses on the integration of MCs following an acquisition. Specifically, the newly acquired firm faces the implementation of a new enterprise resource planning (ERP) system, and organizational restructuring to accommodate SOX processes and IFRS standards. We base our data on interviews with key actors from both the acquiring firm in Canada and the acquired firm in Finland, as well as observation and document analysis.

Our findings show that the mutual trust between superiors and subordinates facilitated enabling perceptions of the new MCs. Managers and other key people from the acquiring company actively engaged in trust-building activities such as demonstrating reliability, competence, and benevolence (Long 2018), to foster positive interpersonal relationships. This, in turn, helped subordinates to accept the explanations given for low participation and low flexibility. Positive interpersonal relationships, reinforced by regular meetings, also provided an alternative way of overcoming the negative consequences of rigid controls. As a result, local employees perceived the MCs as enabling rather than coercive. 
This study contributes to the literature on enabling controls (e.g. Ahrens and Chapman 2004, Jordan and Messner 2012, Wouters and Wilderom 2008) in several ways. Our study develops further the concept of enabling control by going beyond the four original features. Indeed, our findings identified new factors that help employees perceive controls as enabling, including the use of trust-building activities, providing a means to overcome rigidity, and providing a rationale for the rigidity. In doing so, we provide theoretical foundations to apply the concept of enabling perceptions to the context of imposed and rigid controls. We also further develop our general understanding of the role of trust in the making of enabling controls. Based on these findings, we propose a processual framework that links trust to managerial intentions, the development process, and the daily use of MCs.

We also contribute to the literature on the complementary relationship between trust and control (e.g. Long 2018, Tomkins 2001, Vélez et al. 2008), particularly in situations where control system implementation can be interpreted by employees as a sign of mistrust (Christ 2013, Christ et al. 2008). We provide empirical evidence to show how managers use meetings to actively balance trust and control in their relationships with subordinates and how this, in turn, fosters positive attitudes towards the control system. Furthermore, while Long (2018) examined the various ways that managers use controls and trust-building activities to motivate subordinate cooperation, we show the actual impact these actions can have on the attitude of subordinates and their perceptions of the controls. In these ways, we also contribute to the debates on the interrelationships between different kinds of MCs (Grabner and Moers 2013, Malmi and Brown 2008, Otley 1980). 


\section{Literature review and theoretical development}

The concepts of enabling and coercive formalization (Adler and Borys 1996) have been used extensively in management accounting literature. In this section, we will define these concepts and review the literature that has used them to tease out their association with the perception of MCs. Following that, we will explore other factors that could induce employees to perceive controls as enabling. Specifically, we will look at managerial intentions for implementing controls, with a specific focus on trust (or the lack of). Other reasons for implementing controls will include post-acquisition integration and regulations such as SOX.

\section{Conceptual background - enabling formalization}

Enabling formalization is defined as formalization that aims to support employees in their work tasks (Adler and Borys 1996). Under an enabling type of formalization, "procedures provide organizational memory that captures lessons learned from experience" and "codifies bestpractice routines so as to stabilize and diffuse new organizational capabilities" (Adler and Borys $1996,69)$. A formalized system will be perceived as enabling by employees if they feel it facilitates their work (Adler and Borys 1996). In turn, this will increase their willingness to use the system (Mahama and Cheng 2013) and generate positive attitudes towards it (Adler and Borys 1996, Wouters and Wilderom 2008). This forms a virtuous circle where the more employees feel the system helps them, the more they use it and the more their task performance improves (Mahama and Cheng 2013).

By contrast, coercive formalization is defined as formalization that forces reluctant compliance and effort (Adler and Borys 1996). Under a coercive type of formalization, 
"procedures are designed to highlight to superiors whether subordinates' actions are in compliance" (Adler and Borys 1996, 71) with the aim of sanctioning deviation. Whether it is because employees are seen as error-prone or as lazy, procedures and systems are designed to be foolproof, and thus, replace the skills and discretion of the employees (Adler and Borys 1996, Ahrens and Chapman 2004). A formalized system will be perceived as coercive if employees feel it facilitates the tasks of their supervisors rather than their own (Adler and Borys 1996). In turn, employees will reciprocate their manager's lack of trust by reducing their own effort, or by trying to circumvent the system (Ibid), thus forming a vicious circle.

\section{Factors contributing to enabling controls}

In their seminal paper, Adler and Borys (1996) argue that several factors contribute to the enabling nature of formalization including involving employees in the process of designing and implementing the system, as well as certain design features of the system.

In the management accounting literature, the design and implementation phases are often combined and addressed as the development process (Englund and Gerdin 2015, Wouters and Wilderom 2008). Since the goal of enabling controls is to facilitate the work of employees, users will participate in the writing (design) and initial adjustments (implementation) of new procedures (Adler and Borys 1996). Specifically, Wouters and Wilderom (2008) found that a development process can contribute to the enabling nature of controls if it is: (1) experiencedbased, building on existing skills and local experience; (2) allows experimentation; and (3) builds on employee professionalism. Indeed, since the new procedures often have to compete with 
existing local systems (Goretzki et al. 2018), employee participation in the development process increases the likelihood that procedures will result in productive outcomes (Adler 2012).

Building on the usability approach to technology design, Adler and Borys (1996) suggest that four design features, i.e. repair, internal transparency, global transparency, and flexibility, can enhance the enabling nature of formalization. Repair refers to the non-routine tasks of repairing and improving procedures. Under an enabling approach, users are provided with the ability to fix issues with procedures and controls (Chapman and Kihn 2009). Deviation is seen as an opportunity to learn, provide training to users, and improve procedures (Adler and Borys 1996), rather than as a threat to authority (Adler et al. 1999).

Internal transparency means understanding the nature of the procedure (Chapman and Kihn 2009). Under an enabling formalization approach, managers want employees to understand the inner workings of procedures and, therefore, information regarding how they work is provided to them (Adler and Borys 1996) in a way that prevents information overload (Ahrens and Chapman 2004). This helps employees understand the tasks at hand (Chapman and Kihn 2009). Managers can also provide information regarding the logic of a procedure and its rationale (Adler and Borys 1996) to help employees understand why it is important.

Global transparency refers to "the understanding of where and how the local processes fit into the organisation as a whole" (Chapman and Kihn 2009, 152), and whether employees have this understanding or not. When a control provides global transparency, employees understand the upstream and downstream interdependencies of their work (Jordan and Messner 2012). This can be achieved by sharing information across the broader system to ensure employees 
understand where their tasks fit (Adler and Borys 1996). For example, communicating the budget process as a whole, or providing the key targets of one unit to other units, will increase global transparency (Ahrens and Chapman 2004).

Finally, Flexibility means allowing users to deviate from the procedures if needed in order to increase the usability of the system (Adler and Borys 1996). In the context of MCs this can be seen as tailoring procedures to the needs of subunits (Ahrens and Chapman 2004). Providing organizational members the discretion over the use of MCs, by giving them the opportunity to adjust global controls to local circumstances (Jørgensen and Messner 2009), or to turn them off under certain circumstances (Chapman and Kihn 2009), contributes to the enabling nature of controls.

Characteristics of enabling control and their association with enabling perceptions

The factors described above should enhance employees' perceptions that controls are enabling. However, the association between individual design features and the perception of controls as enabling is not evident. On the one hand, the presence of a design feature might not lead to enabling perceptions. For example, although increasing internal and global transparency should yield enabling perceptions, Jordan and Messner $(2012,560)$ argue that transparency can open up "the possibility to identify incompleteness in the control system, which may entice managers to question the system". Transparency could also encourage competition between actors and be associated with feelings of being scrutinized (Free 2007). Indeed, increasing global transparency could lead to a shift in how managers use MCs from being seen as a sensemaking device, towards being seen as a surveillance tool (Englund and Gerdin 2015). Other negative reactions towards 
enabling features include actors experiencing flexibility and transparency as distressing, when they are not aligned with their professional competence (Henttu-Aho 2016). On the other hand, the absence of one feature might not automatically lead to coercive perceptions (Dowling and Leech 2014), especially if other controls are perceived as enabling (Englund and Gerdin 2015).

Focusing on either the development process or the design features of management control systems, which is what prior literature mainly does (Goretzki et al. 2018), or treating design features as standalone, could lead to an incomplete understanding of enabling formalization and its outcomes (Englund and Gerdin 2015). Whether employees perceive controls as enabling or coercive seems to be influenced by the situation at hand (Henttu-Aho 2016), the balance (or imbalance) between the design features (Cools et al. 2008), and the characteristics of other controls in the organization (Englund and Gerdin 2015). This suggests that while the features and the characteristics of the development process are associated with enabling controls, there may be other factors that influence an enabling perception by employees.

\section{Conceptual background - other factors facilitating the enabling nature of MCs}

The way Adler and Borys (1996) define the concepts of enabling and coercive formalization combines two different points of view: managerial intentions behind the implementation of controls (to enable employees or to coerce them), and how employees perceive these controls (as enabling them or coercing them) (Tessier and Otley 2012). These two points of view are interrelated since, as argued by Jordan and Messner (2012), control systems are a matter of interaction between managers and employees. According to these authors, whether employees 
"regard a system as enabling for their work will to an important extent depend on how top management uses that system for control purposes" (Jordan and Messner 2012, 546).

The role of trust

When considering managerial intentions, an important factor to consider is whether managers trust their employees or not. Trust is "a psychological state comprising the intention to accept vulnerability based upon positive expectations of the intentions or behavior of another" (Rousseau et al. 1998, 395). Factors that affect trustworthiness usually include reliability (or integrity), competence (or ability), and benevolence (Mayer et al. 1995) ${ }^{1}$. Reliability depends on whether the trustors believe the trustee adheres to a set of principles they find acceptable (Mayer et al. 1995). Competence depends on whether the trustors believe the trustee has the necessary set of skills to execute activities in a specific domain (Emsley and Kidon 2007), or at least influence the specific domain of activities (Mayer et al. 1995). Benevolence depends on whether the trustors believe the trustee wants to do good to the trustors (Mayer et al. 1995).

When managers trust their employees, they may implement and use controls with the intention of enabling them to perform their tasks better (Adler and Borys 1996), rather than to control opportunistic behavior (Free 2007). Enabling formalization builds on employees' competence and assumes they are reliable. On the other hand, if managers do not view their employees as trustworthy, they may implement controls to coerce them into increasing their effort (a lack of benevolence towards managers), or to prevent them from doing certain things that would be harmful to the organization (a lack of reliability). This is best illustrated by Ahrens

\footnotetext{
${ }^{1}$ There are different lists of factors using different terminologies (see Mayer et al. 1995, 718). In this paper, we use reliability, competence, and benevolence, based on Long's (2018) trust-building activities.
} 
and Chapman $(2004,286)$ where head office managers" "coercive vision of control systems" was fueled by mistrust. Indeed, head office managers thought restaurant managers lacked reliability and competence.

Thus, trust (mistrust) can influence why controls are being implemented and how these controls are designed (Adler et al. 1999). However, because the concept of trust is rarely considered in studies investigating enabling controls, with the exception of Ahrens and Chapman (2004) and Goretzki et al. (2018), it is not clear how trust (or the lack of it) affects the perception of controls. According to Adler and Borys (1996), a lack of trust by management could lead to employees having negative attitudes towards control systems. Indeed, as the authors mention, if "staff analysts formulate procedures in distrustful isolation from line employees, it is not surprising that those employees resist the resulting system" (Adler and Borys 1996, 75). They also suggest that "employees inevitably will reciprocate management's lack of trust" $(1996,70)$. This is also illustrated by Ahrens and Chapman's (2004) study since restaurant managers did not trust head office managers either. Indeed, restaurant managers thought that head office managers lacked competence and benevolence. The restaurant managers' lack of trust towards the head office managers meant that they also doubted the controls and, therefore, perceived them as coercive (i.e. solely as a control device for top management).

Trust also plays an important role in the use of management control systems. Indeed, Goretzki et al. (2018) argue that if local employees do not trust the new global system, they may reject it and continue to use the old systems as a "defensive resource" (see also Kilfoyle et al. 2013). What is less clear is the role of trust in circumstances where managers trust their employees but have to impose controls for other reasons such as improving the coordination 
between employees, streamlining processes, complying with regulations, or mitigating risk (Christ 2013). In these instances, imposing controls might not be a sign of mistrust (Ibid).

Circumstances for imposing MCs and factors influencing the perception of such MCs

M\&A are a fertile ground for the implementation of controls that are being imposed upon an organization. Rapid growth through M\&A typically increases the levels of complexity within different functions of a corporation, and managing interdependencies between these functions creates a strong need to formalize and integrate MCs (Chenhall 2003, Markus 1983, Roberts 1990). A participative design and implementation process of control systems (Wouters and Roijmans 2011, Wouters and Wilderom 2008) rarely happens in cases of acquisitions, as controls are often implemented top-down (Granlund 2003, Jones 1985). In fact, experienced acquirers tend to move fairly quickly with the post-acquisition integration process (Haspeslagh and Jemison 1991) to avoid prolonging the stressful uncertainty usually experienced by employees in the acquired firm (Cartwright and Cooper 1993). Thus, top-down implementation with little participation from the acquiree is often favored. Another example of imposed controls is those implemented to comply with financial regulations such as SOX to ensure reliable internal controls, record retention, and fraud detection. To comply with SOX, controls must be put in place despite the amount of trust managers may have in their employees.

Although controls may be imposed for reasons other than mistrust, employees might still interpret the implementation of such controls as a sign of mistrust, which could negatively affect their intrinsic motivation and willingness to comply with the directives (Christ et al. 2012, Christ et al. 2008). Research on the matter suggests that employees are more likely to have a negative 
reaction to a control system if they think the reason for implementing it is endogenous, i.e. imposed by management (Christ 2013). When the rationale for implementing the system is exogenous, i.e. external to the superior, subordinates are more willing to accept it, especially if the reasons are well explained to them (Christ 2013, Korsgaard et al. 2002).

An acquisition can be a credible explanation to help local management rationalize why controls are being implemented and could reduce negative attitudes towards said controls. However, this explanation might not reduce any negative attitudes employees might have towards the managers of the acquiring firm (Goold and Campbell 1987, Marks and Mirvis 1985, 1997, Roberts 1990). Therefore, we suggest that building and fostering relationships based on mutual trust between the acquiring and acquired firm could facilitate enabling perceptions of controls in the post-acquisition integration.

\section{Summary of our theoretical development}

We conclude this literature review with a summary of our theoretical development that is based on the combination of the conceptual background on enabling controls, and the conceptual background on other factors facilitating enabling perceptions of controls. Trust influences why control systems are implemented and how they are designed (Adler et al. 1999), which might affect how employees perceive controls (Adler and Borys 1996, Adler et al. 1999). While there are known factors that can enhance enabling perceptions, such as certain characteristics of the development process and certain features of the control systems (Adler and Borys 1996, Wouters and Wilderom 2008), not all factors need to be present in order to lead to enabling perceptions. The situation itself, the characteristics of other control systems, and how much the control 
system constrains employees, seem to influence enabling perceptions. In some circumstances, it might not even be feasible to have all the features in place. If circumstances prevent managers from designing controls in a way that would signal their level of trust towards employees (e.g.: post-acquisition integration, compliance to regulation), managers should actively foster trust through trust-building activities (Long 2018), and communicate their intentions behind the implementation of the MCs (Christ 2013) to facilitate enabling perceptions of these MCs. These theoretical propositions will be further explored in the remainder of the paper through our case study.

\section{Research Design}

\section{Case Selection}

Our paper draws on a qualitative case study conducted across two sites within a single organization, Gretzky based in Canada, and Finski based in Finland (both names changed). Finski, which used to be a separate entity, was acquired by and integrated into Gretzky in 2010 . We chose this organization, because Gretzky is a stock-listed firm that: (1) has to comply with SOX; (2) operates under a global organizational model based on the centralization of assets, resources, and responsibilities (Bartlett and Ghoshal 2002). Thus, after the acquisition, Finski became a manufacturer and a distributor within Gretzky's organizational structure.

The acquisition context is relevant to our study because acquisitions and SOX compliance are circumstances that pose a challenge to MCs being perceived as enabling by employees of the acquired firm. This gives us an opportunity to look at other factors that may facilitate enabling perceptions during and after the implementation of new MCs. Moreover, a situation where new 
relationships are being forged is typically characterized by a lack of trust at the beginning, particularly by the acquired party (Das and Teng 2001), which provides an opportunity to explore the role of trust-building in the MCs integration process.

\section{Data Collection}

Our research relies on three main methods of data collection: observation, interviews, and document analysis. One of the authors worked for Finski during the integration process from June 2010 to September 2012, experiencing the implementation of management controls first hand. While this observation phase was not done with a conscious research question in mind, it led to the identification of the research problem.

In 2013, when the interview process started, none of the authors were working for the case firm. Interviews were conducted at different organizational levels with key actors who had been involved in the implementation of MCs. In total, 32 semi-structured interviews were conducted between October 2013 and February 2014 by the author who had previously worked at Finski (see Appendix 1).

Because of the author's previous involvement with Finski, the interviews within Finski were carried out first. While conducting these 18 interviews, we used the snowball technique (Miles and Huberman 1994) to identify the actors in Gretzky who should be interviewed. Specifically, we asked Finski's interviewees with whom they were most involved regarding the new ERP systems and MCs. After collecting the names of these key people, we carried out 14 interviews with Gretzky's actors including the CFO, several corporate level managers, and other key players who were in charge of Finski's integration process. 
The interviews were audio-recorded and transcribed using OneNote 2010, which allows the audio recordings to be linked to the transcriptions (Tessier 2012). In addition to these interviews, we also had several informal conversations during coffee breaks and over lunch with employees from both sites ${ }^{2}$. Field notes were taken afterwards. These informal conversations allowed us to further deepen our understanding of each site (Eisenhardt 1989).

Documents such as organizational charts, annual reports, financial disclosures, and internal performance measurement reports were collected and analyzed (see Appendix 2 for more details). To avoid ex post rationalizations of the interviewees, the information obtained from each interviewee was compared with the documents (Sandelin 2008) and checked against the information provided by other interviewees (Miller et al. 1997).

\section{Data Analysis}

Data analysis was carried out through an iterative process between our data and the theoretical background. We started by familiarizing ourselves with the data through reading the interview transcripts and the field notes, to understand how the controls were implemented and how they affected different members of the organization. We conducted within-case analysis (i.e. Finski and Gretzky) and used context charts to map the interrelationships between different key people and their roles (Huberman and Miles 2002).

We also reduced the data using tables (Huberman and Miles 2002) in which we classified controls using the enabling and coercive concepts. Specifically, one of the authors classified

\footnotetext{
${ }^{2}$ These informal conversations happened during the interview phase while no authors were working for Finski.
} 
interviews by control systems (e.g. SOX, ERP, etc.), and then by each dimension and feature (development process, repair, flexibility, internal transparency, and global transparency), to see how interviewees described the new controls. This classification was then challenged and discussed between all the authors. Against our expectations, Finski employees reacted positively to the control systems, so we looked deeper into the data and the literature to explain why. We re-analyzed our data in terms of the specific circumstances of our case (need to integrate, pressures to comply with SOX), and the impact these had on the development process and the features referenced above. This highlighted the need to also consider managerial intentions. However, it was not until we looked into the role of trust and trust-building that preliminary patterns and emerging themes started to connect $^{3}$. These were then compared to our observations, interviews, and documents to make sure they were supported. Finally, we compared our data analysis to theoretical concepts and previous research, in an effort to contribute to the existing literature (Lukka and Modell 2010).

Because one of the author's prior involvement with the organization may raise potential concerns due to the lack of distance in analyzing the findings, the other two co-authors played a central role in enhancing the point of view of outsiders (Lukka and Modell 2010). Spending a year away from the site before conducting the interviews also helped to avoid "going native" (Miles and Huberman 1994). On the other hand, the author's prior involvement helped to gain the trust of the interviewees and "learn the ropes" (Mundy 2010), enhancing the validity of the study.

\footnotetext{
${ }^{3}$ We are grateful to one of our anonymous reviewers for suggesting Long (2018) as theoretical support for our emerging findings.
} 
Indeed, interpretive research requires an insider's view to understand the meanings being analyzed (see Lukka and Modell 2010).

Next, we provide contextual background on the acquisition and the need to integrate Finski into Gretzky's MCs. Then, we present our findings regarding the development process of these MCs. This will be followed by our findings on Finski's daily use of the MCs.

\section{Circumstances surrounding the post-acquisition integration process}

In March 2010, Gretzky announced that it would be acquiring Finski and integrating its operations to serve Gretzky's global customers. Gretzky, a stock-listed company, had made several acquisitions before acquiring Finski, a smaller, privately owned company. Both companies operated in the telecommunications industry and offered business-to-business products. Gretzky's products were mainly off-the-shelf, whereas Finski's products were customized project-specific solutions.

\section{A "friendly" takeover}

Finski's acquisition was aligned with Gretzky's long-term strategy of acquiring complementary technologies in high-growth markets and increasing penetration within certain essential customer sectors. Finski managers explained that since their products complemented Gretzky's, the acquisition was a good way to create synergies between the two companies. Finski managers also mentioned that the acquisition was necessary to ensure the survival of the organization, since many mergers had already occurred in their sector. As a result, the acquisition was described as a friendly takeover, as one manager explains: 
This acquisition was not a hostile takeover, but actually a friendly one. I believe Gretzky was seeking growth and had good intentions. (Manager, Sales 2, Finski)

During the initial months following the acquisition, Gretzky did not change Finski's organizational structure. However, six months after the acquisition, Finski's CEO left the company and the organizational structure was changed drastically. Gretzky never appointed a local CEO or president. Instead, the old organizational structure was replaced by Gretzky's organizational model. New chains of accountability between Gretzky superiors and Finski subordinates were formed. Finski's former VPs became directors or managers, who reported directly to Gretzky's global VPs and directors located mainly in Canada or the United States.

\section{The need to integrate MCs}

Following the acquisition, the most influential change in Finski was the implementation of Gretzky's MCs. Indeed, before the acquisition, MCs within the two firms were very different. Finski was a classical high-tech R\&D company relying on informal controls, which is typical for smaller R\&D firms (Taipaleenmäki 2013). On the other hand, Gretzky relied heavily on formalized control systems, partly because the organization was managed in a centralized way, and partly because of external pressures from investors and legislation (IFRS, SOX, etc.). SOX compliance was very important for Gretzky's top management since failing to ensure adequate internal controls could have severe consequences. As succinctly stated by Gretzky's CFO:

If the SOX controls failed, I would be in jail! (CFO, Gretzky)

The implementation of Gretzky's MCs was mainly done by integrating Finski into Gretzky's ERP system. The integration covered all the major modules: financial accounting, controlling, 
production planning, materials management, sales, and distribution. There were several reasons for this. As a listed entity, Gretzky needed to consolidate the financial information of the two companies. This was critical, since Finski's former ERP system was based on Finnish accounting standards and Gretzky used international accounting standards ${ }^{4}$. The ERP system was also critical to ensure SOX compliance, as stressed by Gretzky's CFO:

This is the reason why we decided to have [Finski] in the ERP also: to have it on the same tools; improving the control, because the ERP is strongly related to SOX, this is very critical. (CFO, Gretzky)

Thus, it was decided that Finski had to abandon its old ERP system and implement the one used by Gretzky. During the ERP integration, Finski's accounting standards were changed to IFRS, job descriptions were introduced, and internal controls were strengthened to comply with SOX (e.g. segregation of duties). These controls established new procedures for every function. For example, the Sales function had to adopt a stricter policy on revenue recognition, the R\&D function had to change their method for calculating transfer prices, the Operations function had to change their method of inventory valuation, etc.

In the next section, we will look at how this integration process was carried out.

\section{A development process accompanied by trust-building activities}

The integration process took place mainly over a period of two years, from 2010 to 2012. During this period, interpersonal relationships between the two firms were developed and MCs were

\footnotetext{
${ }^{4}$ For example, Finnish Accounting Standards allow firms to capitalize part of their R\&D costs, which was used to a great extent in Finski, whereas Gretzky followed IFRS and recorded R\&D costs as expenses.
} 
implemented. Although these two activities occurred simultaneously, they are presented separately for reasons of clarity.

\section{Building interpersonal relationships based on trust}

According to Mayer et al. (1995), conditions leading to trustworthiness include reliability, competence, and benevolence. Being an experienced acquirer, Gretzky had formal procedures for assessing and evaluating the trustworthiness of any new subsidiary. As Gretzky's CFO explained:

We need to assess what the culture of the company is, regarding cultural fraud, we don't want to be associated with theft, any bad behaviour, mafia. (CFO, Gretzky)

Gretzky's top management established that in the case of Finski, reliability was not a problem and that Finski's personnel adhered to the same principles as they did. This did not go unnoticed and Finski employees became aware that Gretzky managers trusted them. As one director explained:

In Gretzky they have noticed that they can trust us Finns to always obey rules. I feel like we share a similar culture with Gretzky, same values, like honesty, justice and fairness. (Director, Operations, Finski)

However, while Gretzky managers trusted Finski, it was not as easy for Finski employees to trust Gretzky. Although Finski employees thought the acquisition was a good strategic fit, they did not know what to expect in terms of their new relationships with Gretzky. As Finski's human relations manager explained:

It is a shock for the employees of the acquired firm; it raises their fear of someone coming here to micro-manage and tell them what to do. (Manager, Human Capital, Finski) 
Gretzky managers recognized that Finski employees hesitated to trust them at the beginning. As one manager said,

it is difficult as a manager to get my employees to talk to me, to open up. I find that with Finnish people it takes a bit longer for them to have trust in you and to open up. (Manager, Services EMEA, Gretzky)

This is not surprising as benevolence is the most difficult factor of trustworthiness to assess in a new relationship (Mayer et al. 1995).

To overcome this, Gretzky managers made considerable effort to build positive interpersonal relationships with Finski employees. According to Long (2018) this can be done by demonstrating benevolence. One way of doing this is to get to know the trustees and make an effort to identify their personal interests. As one of Gretzky's analysts mentioned:

sometimes having a coffee or just talking about something else other than the project... that makes the project easier to work on afterwards because you know the person more personally. (Analyst 1, ERP Configuration, Gretzky)

Thus, Gretzky managers visited Finski several times during the integration. As explained by one manager:

We need to meet first if we want to build trust and have a good collaboration. Over the phone, it is difficult. We need to meet face to face and we did it several times. In fact, we went over there [to Finland] right at the beginning of the integration. (Manager, IT, Gretzky)

Key people from Finski, those involved in the integration process, also visited Gretzky's headquarters in Canada. Gretzky's efforts to foster relationships were recognized by Finski managers as one director explained: 
He [my supervisor] has actually spent a lot of time getting to know us, what we do here, who we are, and also to learn what sort of a person I am. (Director, Operations, Finski)

As will be explained next, both parties also learned to trust each other's competence and work together to successfully carry out the implementation of the new MCs.

\section{A participative development process ... at first}

For Gretzky managers it was important to demonstrate that they could successfully carry out the integration process. According to Mayer et al. (1995), trustees can be trusted to be competent if they possess a group of skills to accomplish tasks related to their area of expertise. Gretzky managers had gone through several integrations before and thought they had developed a certain expertise on the matter, as one director stated:

We implement the way we work everywhere. [...] We have made a lot of acquisitions; it's always the same pattern. (Director, Financial Reporting and Accounting, Gretzky)

One way of demonstrating this competence was to carry out the integration process quickly and firmly to show that there was no hesitation or uncertainty. As described by one of Gretzky's analysts:

In these kinds of projects, you don't want to fool around and hesitate: "Oh, I don't know...". It is important that they [Finski] understand, you know, that these decisions won't change in two weeks, when it's decided it's okay, we go and do it. (Analyst, Logistics, Gretzky)

Being competent also meant that Finski's local contingencies needed to be integrated successfully into Gretzky's systems. To achieve this, Gretzky managers relied on local knowledge by involving key people at Finski. Indeed, involving employees can not only have a positive effect on attitudes, but also on the technical outcome (Adler and Borys 1996), as it helps in the design of more valid and reliable controls (Wouters and Wilderom 2008). Gretzky managers used the 
frequent meetings described in the previous section to build on the experience of Finski managers. One of Gretzky's directors described this process:

We discussed with [Director, Finance, Finski] to make sure that we understood how they were preparing the [month-end reports] and the accruals, things like that. (Director, Financial Reporting and Accounting, Gretzky)

This was also acknowledged by Finski:

The learning was mutual in terms of how things should go into the ERP and how to take the next step. (Director, Operations, Finski)

Local requirements needing customization included bank statements and the filing of corporate tax returns. Additionally, since Finski's products were very different from Gretzky's and involved considerable R\&D related work, Gretzky managers took the time to learn how Finski's customized products could be added to the ERP system.

Ultimately, these configurations were done successfully. This convinced Finski that Gretzky had the ability and the skills needed to proceed with the integration process. It also demonstrated that Gretzky was willing to ask questions and listen rather than only rely on their past experiences. As one of Finski's directors summarized:

They [headquarters] have done so many integrations before that they knew what to ask from us to identify the specificity of our business. (Director, Operations, Finski)

This participative development process based on the mutual acknowledgement of each other's competence and the demonstration of benevolence, helped build positive relationships and foster mutual trust. However, this trust would be tested towards the end of the integration process, as described next. 


\section{Switching to a top-down implementation process - a test of trust}

As the implementation process evolved, Gretzky managers realized that Finski did not have the appropriate MCs in place to comply with SOX. As one of Gretzky's directors described:

We had some challenges with SOX, because there was a lack of controls [at Finski], especially monitoring controls, a lack of reviews, things like that. (Director, Financial Reporting and Accounting, Gretzky)

As a result, the integration process proved to be more difficult than anticipated. One major issue was the segregation of duties. For example, before the acquisition, it was normal practice for Finski's accounts payable accountants to enter invoices into the old system and pay them without anyone else checking and approving the payments. Thus, Gretzky's managers needed to make critical changes to the job descriptions of Finski employees, changes for which there was no room for negotiation or discussion.

By the end of 2011, time was running out to achieve SOX compliance, since listed companies can only exclude newly acquired units from the internal control assessment for the first fiscal year. This increased the time pressure on the integration process, as Gretzky's CFO explained:

We need to document controls, so this is one reason why we pushed the ERP system a little bit faster. (CFO, Gretzky)

Pressures relating to accountability issues were a real concern, as explained by one of Gretzky's managers:

It's not that we want to do everything, but we want to know what's happening [...] because in the end, we are the ones who are responsible for it. (Manager, Corporate Purchasing, Gretzky) 
Consequently, the implementation process of the ERP system evolved from a two-way communication approach into a top-down approach, in the sense that Finski employees stopped taking part in its development. However, according to Gretzky managers, this was not their preferred way of doing things:

Normally we, for sure, would prefer to have worked with the [local] Finance team during this project. (Manager, IT, Gretzky)

Moreover, while Gretzky was open to adapting the system to account for local contingencies, this had to be done with parsimony. Indeed, since the procedures were standardized across the global organization, customizing the ERP system could cause problems for Gretzky, especially during system updates. As one analyst explains:

We try not to customize too much with the ERP, because if we do too much customizing each time we purchase a company, it's going to get bigger and bigger, and if it's too big, it's going to cost a lot to make even small changes. (Analyst 1, ERP Configuration, Gretzky)

The switch to a top-down approach could have altered the development of the interpersonal relationships between Gretzky managers and their new subordinates (Long 2018). Isolating employees from the implementation process could have led to employees resisting or rejecting the new controls (Adler and Borys 1996). However, as explained by Christ (2013), this can be mitigated by explaining the reasons behind a top-down approach. For Gretzky, it was very important to ensure that Finski employees understood that the MCs had to be imposed on them, because of exogenous constraints and not because of mistrust. As Gretzky's CFO explained:

[...] SOX requires those controls to be documented. It's not that we don't believe that [Director, Finance, Finski] is really good and she is honest and so on, but in court you are not going to win anything with that. (CFO, Gretzky) 
These exogenous constraints were an opportunity for Gretzky to demonstrate their reliability (Long 2018). Indeed, Gretzky managers stayed true to their word and did not use exogenous constraints as an excuse to just impose any controls. First, they allowed Finski to keep some of their local procedures, as confirmed by one of Finski's directors:

Actually, we have been able to keep some procedures and methods, even though the global processes are very similar. (Director, Operations, Finski)

Second, when possible, MCs were still developed using local knowledge (Wouters and Wilderom 2008). For example, many of the local Key Performance Indicators (KPIs) were designed together with Finski's directors:

My supervisor told me that I needed to have KPIs and we built them as we mutually agreed, some of which I specifically chose to have. (Director, Operations, Finski)

Third, Gretzky even went a step further and integrated some of Finski's processes into their own. For example, Gretzky changed their vendor payment process based on Finski's own process. Indeed, Gretzky at the time still paid their vendors by check, while Finski was using electronic payments. One of Gretzky's analysts explained how they learned to handle electronic payments from Finski, and then use it at their headquarters:

...one year after the "go live" we implemented electronic payments here [headquarters], because of the perfect experience with Finski. ... in a way Finski opened the door for us to go down this road of electronic payments. (Analyst 3, ERP Configuration, Gretzky)

By building on Finski's know-how when possible, Gretzky managers gave credibility to their rationalization regarding the instances when participation was not possible. As such, Gretzky's efforts to continue to build relationships with Finski employees helped to avoid any negative attitudes towards the new systems, despite the switch from a participative to a top- 
down implementation process. In the next section, we provide our findings on the use of these controls.

\section{Using the new controls on a daily basis}

Once the implementation phase was completed, Finski employees had to do their job under the restriction of the new controls. This was not always easy, because of the rigidity and low flexibility of these controls.

\section{Issues with rigid controls}

The ERP is an integrated system, so it's rigid, meaning that everything is connected together. So, if you want to make a change here, it's not only your part you're going to change. So, it could be a two-minute change for you, but it could impact the whole chain. So, with this sometimes people get frustrated on the operations side. (Analyst 1, ERP Configuration, Gretzky)

The rigidity of the system described above by Gretzky's analyst is not surprising as the functioning of integrated systems is typically based on best practices and standardization (Chapman and Kihn 2009). Moreover, changes to processes are believed to require a global view of the organization, or as Jørgensen and Messner (2009) call it, "the big picture", especially for repairs that affect more than one function. However, in Gretzky's organization, local management did not have this overview, as explained by one of Finski's directors:

In Gretzky's organization model the Sales, Business management, and R\&D are very much separated. [...] I sit far away from the headquarters and I have to rely on the information that I'm given, so I have less visibility of the whole business nowadays. (Director, R\&D, former VP, Finski)

Thus, the new controls embedded in the ERP system required restricting local managers from making changes to the processes themselves, and reduced the amount of flexibility they had. 
However, these rigid controls were sometimes problematic for Finski. For example, in Gretzky's organization, job descriptions and responsibilities were clearly divided and documented to ensure the segregation of duties, and this was embedded within the ERP access rights. Thus, under Gretzky's segregation of duties, employees were not allowed to go beyond their own tasks. In some situations, this was quite dysfunctional for Finski managers. For example, due to Finski's small teams in accounting and logistics, sometimes the only person with the authority to perform certain transactions was on holiday, and there was no way of getting around this rule. As Finski's Finance director mentioned:

We have had urgent deliveries or orders which couldn't be processed, until a certain person was present to do a certain thing in the system... we have had to call people back from their vacation to do certain things in the system. (Director, Finance, Finski)

Within the Finnish context, calling employees back to work during their vacation is not considered socially acceptable.

Another example of rigid controls causing issues regards the standardization of the sales process. Sales people used to have a lot of flexibility when it came to selling products and could sell whatever clients wanted including products from subcontractors that were outside of Finski's core products. Since Gretzky followed the TL9000 quality management system, this was seen as a risk. Indeed, not all the outsourced products followed the same quality control standards ${ }^{5}$. Hence, under the new MCs, Sales people could only sell products that were already in the ERP system and new products had to be added through a formal process which involved proper

\footnotetext{
${ }^{5}$ TL 9000 is a quality management system built on ISO 9001, but designed specifically for the communications industry. Its purpose is to define the unique communication quality system requirements for design, development, production, delivery, and service.
} 
quality checks. However, sometimes adding new products would take too long and a competitor would win the deal, as a Finski manager described:

Processes are good, but if they slow your growth down or prevent sales, then they are unnecessary [...] The customer tells you that he has 15,000 dollars to spend, and you have to reply to him that we don't have that item in the ERP so I can't sell it. (Manager, Sales 2, Finski)

As the two examples above imply, the rigidity of the new controls was causing some frustration among Finski managers.

\section{Factors fostering enabling perceptions}

Although the ERP system and the MCs were imposed on Finski and were quite rigid, two factors fostered enabling perceptions: (1) being able to rationalize the rigidity by acknowledging the improvements brought about by the new controls; (2) having positive relationships with managers which make it easier to ask for help to overcome the rigidity.

Rationalizing the rigidity by acknowledging improvements

Having standardized procedures and rigid controls was quite a change for Finski employees, and as shown previously was sometimes inconvenient. However, because Gretzky had taken the time during the development process to explain the reasons behind this rigidity, Finski managers associated the inflexibility of the processes with standardized rules. This demonstrated a clear understanding of why flexibility and repair opportunities were reduced. As one of Finski's directors explained:

It is difficult to try to deviate from the processes, since this is a Nasdaq-listed company where we have to comply with SOX - we cannot change processes just like that. (Director, Finance, Finski) 
Finski managers understood that modifications done locally by employees who do not have a global view of the organization could create problems for the organization as a whole, as highlighted below:

They could make a great decision for example in the sourcing function, which can have a catastrophic impact on the logistics function. (Director, Finance, Finski)

They were also able to rationalize the reduction in visibility as a normal consequence of being part of a bigger company, as the following quote implies:

We have this background of being a smaller firm where people used to have many different roles which required an understanding of the bigger picture [...] But of course, it is different when your organization is bigger. (Director, Finance, Finski)

Finski employees could also see the benefits of the rigidity. For example, standardized processes ensured transactions were done correctly, which in turn increased accuracy and predictability, as one accountant confirmed:

With the old ERP that Finski was using, a lot of errors were made with accounting tasks [...] the new ERP is better because there are less errors you can make. (Accountant 2, Finski)

The ERP system also increased internal transparency by codifying best practices, providing more tools, more reports, and more information regarding day-to-day activities. This was appreciated by Finski managers as one of the Sales managers explained:

Earlier at [Finski] we didn't have such reporting [...] now I receive listings from the ERP system daily, and a summary on a weekly basis where I can see all the activities entered into my account [...] it has been a positive transformation. (Manager, Sales 1, Finski)

Indeed, while the new process was frustrating for Sales people, over time they understood that standardization had its merits, as the following quote implies: 
[...] now since we follow the process [with new products], which locally seems stiff and inflexible, the customer will have a functioning product and one that we can guarantee works. (Manager, After-Sales Services, Finski)

Understanding why the new MCs had to be rigid was an important factor that helped Finski employees accept and make use of the new systems, which in turn helped them understand the benefits of the new MCs.

Positive relationships and asking for help in overcoming rigidity

Rationalization of rigid controls may not be enough, however, to prevent any coercive perceptions of the new controls. For example, Cools et al. (2008) describes the implementation of a new transfer pricing policy that was implemented for tax purposes (exogenous circumstance) which local managers helped develop (participative development), so they understood why it was implemented. Yet, because it was too restrictive when used daily, it was perceived as coercive.

In our case, because the integrity of the system had to be protected, local managers were dependent on Gretzky for modifications. This was facilitated by the positive relationships developed during the integration process which were maintained afterwards through weekly online meetings. As one of Finski's directors explained:

The way we work is that I report to him [supervisor] on a weekly basis, I'm like "his eyes" here at this plant. (Director, Finance, Finski)

Gretzky managers used these regular meetings to provide assistance with design features not embedded in the controls. Indeed, lack of local repair and global transparency were compensated for by global repair and frequent communication. 
As a Finski manager explained, when problems needed to be fixed, they turned to their superiors at the headquarters:

[...] if we cannot solve a problem by following processes, then we will escalate it upwards. (Manager, Sales 1, Finski)

For example, the previously mentioned problem caused by the segregation of duties and its impact during the holidays was managed globally. Gretzky changed the ERP access rights to make sure there were always at least two people authorized to do the same tasks in the system, forming working pairs that could replace each other. For smaller problems, Finski employees contacted the Gretzky staff dedicated to helping subsidiaries with such problems. These occurred quite regularly as a Finski manager explained:

In practice I contact Headquarters on a weekly basis to ask them to do something in ERP or CRM. Usually it is something I see in the reports or something that is missing from the reports, or I need some adjustments made in the systems, and so on. (Manager, Sales 1, Finski)

Through these meetings, Gretzky's contact people demonstrated their benevolence. For example, whenever a problem could not be fixed by Finski, Gretzky tried to solve the problems as quickly as possible. As explained by one of Finski's accountants:

It always feels that our problems are their number one priority, and they try to find the best possible answer. (Accountant 2, Finski)

Additionally, many of Gretzky's contact people went out of their way to accommodate Finski employees and ensure these meetings would be convenient including coming to work earlier to have more working time together. Hence, these meetings were not perceived as supervision by Finski employees, but rather as a way to address any issues that might come up, as a manager indicated: 
I have weekly meetings with my supervisor and sometimes even more often if needed. I have had the freedom to do my work and I feel trusted. (Manager, After-Sales Services, Finski)

The meetings also helped compensate for feelings of not having the "big picture". Many of Gretzky's managers made efforts to ensure that Finski employees had the information they needed for their daily tasks, a demonstration of reliability according to Long (2018). Sharing information increases global transparency helping employees to understand and relate to organizational strategies (Jordan and Messner 2012). This was acknowledged by one of Finski's directors:

[...] here at Gretzky they are quite open with sharing financial information. Within our division the quarterly information is shared upfront and that gives us a pretty good idea how the business is going in relation to our strategy and so on. (Director, R\&D, Finski)

As explained by Long (2018), these demonstrations of benevolence and reliability help maintain positive relationships and coordination respectively. As such, constraints of the control systems were in fact opportunities to continue building trust. As a result, Finski employees learned to rely on Gretzky's help, as explained by one of Gretzky's coordinators:

[...] they [Finski personnel] understand it more now, that we're there to help and support them. They are not alone, even if we're so far away. (Coordinator, Inventory and Demo Equipment, Gretzky)

Thus, the positive relationships served as a channel for Finski to ask for help, which was often needed, because of the rigidity of the MCs.

\section{New controls perceived as enabling}

In the end, despite the fact that the development process was mostly top-down with little experimentation, and several features associated with enabling controls were rather limited, 
Finski managers still perceived the controls as enabling. One of Finski's directors summarized this:

It has brought discipline, and discipline is a good thing. (Director, Operations, Finski)

As argued by Adler and Borys (1996), routines, checklists, and procedures provide internal transparency, and formalization helps in reducing role ambiguity. One of Finski's managers mentioned that the strict job descriptions used to ensure the segregation of duties helped the organization as a whole to operate in a more structured way.

The new organizational structure and the reporting responsibilities are very streamlined, I think it is working pretty well. (Manager, Sales 1, Finski)

The typical increase in efficiency that follows the implementation of enabling formalization (Adler and Borys 1996) did occur in Finski, as an accountant explained:

Monthly accounting tasks don't require so much time anymore because we have these routines to follow, and the checklist we have is very good; it contains all the phases that need to be done. (Accountant 1, Finski)

While it was harder to have global visibility under the new structure, the ERP system did provide Finski's managers with a lot of information. One director explained that this made his job easier and more efficient.

I see everything from the systems, the sales cases, and so on. I just don't sit in dozens of meetings anymore. (Director, Finance, Finski)

Thus, we conclude that in the end Finski employees reacted positively to the new MCs, and considered the controls as enabling them to better master their work tasks (Adler and Borys 1996). Our results identified several factors contributing to enabling perceptions, including the reasons for implementing rigid controls being explained to Finski employees, the controls proving 
to be useful, and the rigidity of the controls being handled globally. These different factors ensured the controls remained usable for Finski employees.

\section{Discussion and conclusion}

\section{A processual framework to foster enabling perceptions}

By combining our findings with those from previous studies, we propose that enabling perceptions should be viewed as the result of a process influenced by managerial intentions, the development process, and the daily use of MCs (see Table 1). Throughout this process, managerial actions impact employee perceptions.

\section{Insert Table 1 around here}

Since trust is central to the enabling and coercive typology (Adler et al. 1999), the proposed framework explains how controls, which are implemented and used in a way that fosters trust, support enabling perceptions.

\section{Managerial intentions}

According to Ahrens and Chapman (2004), when managerial mistrust of employees fuels the implementation of control (i.e. intentions), employees reciprocate and do not trust their managers, nor do they trust the controls (i.e. perception). On the other hand, when employees feel that their managers trust them, as is the case in our study, they take this into account and do not necessarily perceive controls as coercive. As such, managerial intentions are not disconnected from employee perceptions (Tessier and Otley 2012). Thus, managerial intentions, 
and whether they are based on trust or not, is the starting point of our processual framework (see the "Managerial Intentions" row in Table 1).

Managerial intentions that foster enabling perceptions include implementing controls to support employees so they perform their tasks better (e.g. best practices), as originally defined by Adler \& Borys (1996). They also include, as shown in our case study, implementing controls to comply with exogenous circumstances, such as SOX, or to integrate MCs after an acquisition. Indeed, our findings support the argument that it is easier for employees to perceive imposed and rigid controls as enabling when these are implemented, because of exogenous circumstances (Christ 2013, Korsgaard et al. 2002).

\section{Development process}

We also argue that the role of trust goes beyond managerial intentions. Indeed, our findings show that a development process which fosters trust supports enabling perceptions (see the "Development process" row in Table 1). Trust can be fostered in three ways: (1) managers can foster employees' trust in the new controls; (2) managers can demonstrate their trust in employees; and (3) managers can demonstrate their trustworthiness to employees.

Experimentation during the development process (Wouters and Wilderom 2008) can serve as a means to foster trust in the new control system (Goretzki et al. 2018). This is important, because if local employees do not trust the global control systems, they may end up rejecting them and continue to use their own local systems (Goretzki et al. 2018, Kilfoyle et al. 2013). Providing a rationale for the implementation of new controls, in other words, explaining managerial intentions, can also help build trust towards the new controls, whether these 
intentions are to help employees accomplish their tasks (Adler and Borys 1996), or to comply with exogenous pressures. Indeed, when managerial intentions are explained to employees (Christ 2013), this reduces the possibility that the implementation of control is perceived as a sign of mistrust.

Allowing employees to participate in the development process (Adler and Borys 1996) can help managers demonstrate they trust their employees. Moreover, basing a development process on local knowledge and local experience (Wouters and Wilderom 2008) can be a signal to employees that managers trust their competence. Importing local procedures to the global organization, as was the case in our setting, can also serve this purpose (e.g.: Gretzky adopting electronic payments).

When a new control system has to be imposed, it might not be feasible to allow experimentation or to let employees participate in the development process. Under these circumstances, according to our results, fostering trust in the managers imposing the new controls, by actively engaging in trust-building activities (Long 2018), may foster enabling perceptions. Our study shows that employees that had not experimented with the new controls engaged with them at first, because they trusted the competence and the benevolence of managers implementing them. Fostering trust and building relationships were especially important in our case since it was an acquisition and Finski employees had a lot of uncertainty regarding their new managers. Demonstrating reliability was also important in fostering trust in managers since the rationale for the new controls was based on exogenous circumstances. Indeed, even if managers explain their intentions behind rigid or imposed controls, it does not 
necessarily mean employees will accept their rationale. For example, Adler and Borys (1996) give the example of an organization where employees were quite cynical about management's rationale that new procedures were the result of ISO9000 certification. In our case, Gretzky gave credibility to their rationale by honoring their implicit promise (Long 2018) of imposing controls only when they had to. This is a possible theoretical explanation as to why the presence of other controls, which provide flexibility and repair, foster enabling perceptions of controls that otherwise do not provide these features (Englund and Gerdin 2015). Indeed, the presence of controls that are perceived as enabling serves as a demonstration of the reliability of managers, which prevents employees from interpreting the implementation of rigid controls as a sign of mistrust. Making sure employees accept the rationale for new controls is important because, according to Christ (2013), employee beliefs about managerial intentions influence their behavior.

Daily use

Even if employees understand and accept the reasons why rigid controls are implemented, and trust the managers implementing them, they may still resent controls that constrain them too much on a daily basis (Cools et al. 2008). For employees to perceive controls as enabling, the controls need to be usable (see the "Daily use" row in Table 1).

According to the literature, allowing employees to repair controls themselves (i.e. without hierarchical intervention), providing them with flexibility in terms of how to accomplish their tasks, as well as providing them with internal and global transparency, help to support an enabling perception, because they enhance the usability of the controls (Adler and Borys 1996, Ahrens and Chapman 2004). We argue that designing controls with these features requires 
managers to trust their employees. Indeed, these features are based on a design logic that sees the user as "a source of skill and intelligence to be supported" (Adler and Borys 1996, 68). As such, when managers incorporate these features in the design of new MCs, they are demonstrating trust in their employees' competence (flexibility and repair), and providing them with the information they need to be competent (internal and global transparency).

Exogenous circumstances (ERP system, SOX rules, etc.) might limit the opportunities for local repair and flexibility. Our findings identified factors that fostered enabling perceptions under these circumstances. Firstly, our findings support Jordan \& Messner's (2012) argument that by using the MCs, employees learn to appreciate the benefits of the systems. As the literature suggests, the features that influence enabling perceptions are not equally important (Dowling and Leech 2014, Englund and Gerdin 2015). In our case, internal transparency, which brought clarity and stability to Finski employees, was valued over repair and flexibility. The fact that employees understood why these controls were implemented also played a role in their acceptance of the new controls. Hence, employees engaged with the new controls at first, because they trusted the people implementing them, but they eventually learned to trust the controls per se. Secondly, Gretzky managers provided alternative ways of overcoming the missing features through regular meetings with Finski employees. In doing so, the managers ensured the controls remained usable for the employees. We argue that when design features are replaced by hierarchical interventions, employees need to trust their managers. Indeed, as argued by Mayer et al. (1995), trust can be seen as the willingness to be vulnerable to the actions of someone else, even if the trustor has no influence or control over the trustee. Having to rely on the intervention of someone else to overcome control rigidity may make employees vulnerable. 
Thus, we contend that hierarchical intervention can lead to enabling perceptions, when the relationships between managers and employees are based on trust and supported by trustbuilding activities.

\section{Contributions}

We contribute to the literature on enabling controls (e.g. Ahrens and Chapman 2004, Jordan and Messner 2012, Wouters and Wilderom 2008) by incorporating the concept of trust and further developing its relationship with enabling controls. Indeed, in the management accounting literature that builds on the enabling concept, not many authors mention trust in their studies (see Ahrens and Chapman 2004, Goretzki et al. 2018 for exceptions). As such, our study further develops the "theoretical foundations" of enabling controls as called for by Adler and Borys $(1996,85)$. Our findings highlight the importance of trust as a "fundamental ingredient or lubricant" (Gambetta 1988, foreword) of enabling perceptions of controls, whether it concerns managerial intentions, the development process, or the daily use of MCs. We call for more research that focuses on the potential misalignment between managerial intentions and employee perception of controls (Tessier and Otley 2012). The nature of the development process and the design features could then be used to investigate such misalignment.

We also contribute to the literature on the complementary relationship between trust and control (e.g. Tomkins 2001, Vélez et al. 2008). Our case study provides empirical evidence of how managers use regular meetings to actively balance trust and control in their relationships with subordinates (Emsley and Kidon 2007, Long 2018, Vélez et al. 2008). While Long (2018) argues that managers may build relationships to provide autonomy, our study shows that 
positive relationships can also be used to compensate for a lack of autonomy caused by rigid MCs. Moreover, building on Long (2018), we provide evidence of both the actions of managers and the responses of subordinates to such actions, and show the actual impact that these actions can have on subordinates' attitudes. We also show that while communicating the intentions behind the implementation of rigid controls helps reduce the risk of employees perceiving this as a sign of mistrust, as suggested by Christ (2013), this might not be enough to prevent negative reactions towards the controls. Indeed, rationalization of new controls mainly occurs during the implementation phase. Therefore, even if employees understand why controls are being implemented, the initial positive reaction could change to a negative one if controls are too restrictive to use (see Cools et al. 2008).

On a practical level, our study highlights the importance of trust in interpersonal relationships between headquarters and subsidiaries during strategic changes, such as mergers and acquisitions. As Simons (2005) argues, these relationships are important at the global level for coordinating how the changes are implemented at the local level. Hence, interpersonal communication helps global managers learn about the local situation (Cäker and Siverbo 2014). However, trust in management is required to ensure that employees are willing to share private information about their process, rather than hiding bad results (Wouters and Roijmans 2011). Based on our results, we argue that control systems have great potential in helping to form relationships between global and local managers, and in facilitating the post-acquisition integration process, if implemented with the focus on building mutual trust between the parties. For example, when new control systems are considered as being rigid and inflexible by the locals, this could be an opportunity for global managers to offer support to local managers encountering 
such problems with new controls. As repair requirements can be seen as a dialogue which encourages interaction and enhances communication between individuals (Adler and Borys 1996, Chapman and Kihn 2009), we argue that hierarchical interventions give the global managers an opportunity to demonstrate their trustworthiness to local employees. Implementing MCs in such a way can help avoid the negative effects of increasing formalization on employees (Adler 2012), and the mistrust of management (Johansson and Baldvinsdottir 2003), by increasing interpersonal communication. Frequent managerial communication, in turn, can help reduce the stress and negative behavior associated with post-acquisition integration (Krug 2003, Schweiger and Denisi 1991, Sinkovics et al. 2011).

The context of our study was a post-acquisition integration, which allowed us to investigate the relationship between enabling formalization and new interpersonal relationships between the acquirers and the acquirees, with a focus on trust. However, this specific setting might not be transferable (Lincoln and Guba 2000) to settings where such interpersonal relationships already exist. It would therefore be interesting to investigate the development process of enabling controls in a setting where relationships are already formed. For example, studies could investigate how relationships already based on trust are reinforced or damaged during the implementation of controls, or, in contrast, how relationships already based on mistrust are further damaged or reconstructed through the implementation of new controls. Moreover, since the acquisition described in our case study is a friendly takeover, further research could investigate the factors that help foster an enabling perception of controls in the context of a hostile takeover. 


\section{References}

Adler, P. S. 2012. The Sociological Ambivalence of Bureaucracy: From Weber via Gouldner to Marx. Organization Science 23 (1): 244-66, https://doi.org/:10.1287/orsc.1100.0615.

Adler, P. S., and B. Borys. 1996. Two Types of Bureaucracy: Enabling and Coercive. Administrative Science Quarterly 41 (1): 61-89.

Adler, P. S., B. Goldoftas, and D. I. Levine. 1999. Flexibility Versus Efficiency? A Case Study of Model Changeovers in the Toyota Production System. Organization Science 10 (1): 43-68, https://doi.org/:10.1287/orsc.10.1.43.

Ahrens, T., and C. S. Chapman. 2004. Accounting for Flexibility and Efficiency: A Field Study of Management Control Systems in a Restaurant Chain. Contemporary Accounting Research 21 (2): 271-301.

Bartlett, C. A., and S. Ghoshal. 2002. Managing across borders: the transnational solution. 2nd ed. Boston, MA: Harvard Business School Press.

Burns, T. E., and G. M. Stalker. 1961. The management of innovation. London, England: Tavistock.

Cäker, M., and S. Siverbo. 2014. Strategic alignment in decentralized organizations - The case of Svenska Handelsbanken. Scandinavian Journal of Management 30 (2): 149-62, https://doi.org/:10.1016/j.scaman.2013.10.005.

Cartwright, S., and C. L. Cooper. 1993. The psychological impact of merger and acquisition on the individual: A study of building society managers. Human Relations 46 (3): 327.

Chapman, C. S., and L.-A. Kihn. 2009. Information system integration, enabling control and performance. Accounting, Organizations and Society 34 (2): 151-69, https://doi.org/:10.1016/j.aos.2008.07.003.

Chenhall, R. H. 2003. Management control systems design within its organizational context: findings from contingency-based research and directions for the future. Accounting, Organizations and Society 28 (2-3): 127-68, https://doi.org/:10.1016/S0361-3682(01)00027-7.

Chenhall, R. H., and D. Morris. 1995. Organic decision and communication processes and management accounting systems in entrepreneurial and conservative business organizations. Omega 23 (5): 485-97, https://doi.org/:10.1016/0305-0483(95)00033-K. 
Christ, M. H. 2013. An Experimental Investigation of the Interactions among Intentions, Reciprocity, and Control. Journal of Management Accounting Research 25 (1): 169-97, https://doi.org/:10.2308/jmar-50443.

Christ, M. H., S. A. Emett, S. L. Summers, and D. A. Wood. 2012. The Effects of Preventive and Detective Controls on Employee Performance and Motivation*. Contemporary Accounting Research 29 (2): 432-52, https://doi.org/:10.1111/j.1911-3846.2011.01106.x.

Christ, M. H., K. L. Sedatole, K. L. Towry, and M. A. Thomas. 2008. When Formal Controls Undermine Trust and Cooperation. Strategic Finance 89 (7): 39-44.

Cools, M., C. Emmanuel, and A. Jorissen. 2008. Management control in the transfer pricing tax compliant multinational enterprise. Accounting, Organizations and Society 33 (6): 603-28, https://doi.org/:10.1016/i.aos.2007.05.004.

Das, T. K., and B. S. Teng. 1998. Between trust and control: Developing confidence in partner cooperation in alliances. The Academy of Management Review 23 (3): 491-512.

Das, T. K., and B. S. Teng. 2001. Trust, Control, and Risk in Strategic Alliances: An Integrated Framework. Organization Studies 22 (2): 251-83, https://doi.org/:10.1177/0170840601222004.

Dowling, C., and S. a. Leech. 2014. A Big 4 Firm's Use of Information Technology to Control the Audit Process: How an Audit Support System is Changing Auditor Behavior. Contemporary Accounting Research 31 (1): 230-52, https://doi.org/:10.1111/1911-3846.12010.

Eisenhardt, K. M. 1989. Building Theories from Case Study Research. Academy of Management Review 14 (4): 532-50, https://doi.org/:10.5465/AMR.1989.4308385.

Emsley, D., and F. Kidon. 2007. The Relationship between Trust and Control in International Joint Ventures: Evidence from the Airline Industry*. Contemporary Accounting Research 24 (3): 82958, https://doi.org/:10.1506/car.24.3.7.

Englund, H., and J. Gerdin. 2015. Developing Enabling Performance Measurement Systems: On the Interplay Between Numbers and Operational Knowledge. European Accounting Review 24 (2): 277-303, https://doi.org/:10.1080/09638180.2014.918517.

Free, C. 2007. Supply-Chain Accounting Practices in the UK Retail Sector: Enabling or Coercing Collaboration? Contemporary Accounting Research 24 (3): 897-933.

Gambetta, D. 1988. Trust: Making and breaking cooperative relations. New York, NY: Blackwell. 
Goold, M., and A. Campbell. 1987. Strategies and styles: The role of the centre in managing diversified corporations. Oxford, England: Basil Blackwell.

Goretzki, L., E. Strauss, and L. Wiegmann. 2018. Exploring the Roles of Vernacular Accounting Systems in the Development of "Enabling" Global Accounting and Control Systems. Contemporary Accounting Research 35 (4): 1888-916, https://doi.org/:10.1111/1911-3846.12357.

Grabner, I., and F. Moers. 2013. Management control as a system or a package? Conceptual and empirical issues. Accounting, Organizations and Society 38 (6-7): 407-19, https://doi.org/:10.1016/i.aos.2013.09.002.

Granlund, M. 2003. Management accounting system integration in corporate mergers: a case study. Accounting, Auditing \& Accountability Journal 16 (2): 208-43.

Haspeslagh, P. C., and D. B. Jemison. 1991. Managing acquisitions: creating value through corporate renewal. New York, NY: The Free Press.

Henttu-Aho, T. 2016. Enabling characteristics of new budgeting practice and the role of controller. Qualitative Res Acc \& Man 13 (1): 31-56, https://doi.org/:10.1108/QRAM-09-2014-0058.

Huberman, A. M., and M. B. Miles. 2002. The qualitative researcher's companion. Thousand Oaks, CA: SAGE.

Johansson, I.-L., and G. Baldvinsdottir. 2003. Accounting for trust: some empirical evidence. Management Accounting Research 14 (3): 219-34, https://doi.org/:10.1016/S10445005(03)00045-3.

Jones, C. S. 1985. An empirical study of the role of management accounting systems following takeover or merger. Accounting, Organizations and Society 10 (2): 177-200, https://doi.org/:10.1016/0361-3682(85)90015-7.

Jordan, S., and M. Messner. 2012. Enabling control and the problem of incomplete performance indicators. Accounting, Organizations and Society 37 (8): 544-64, https://doi.org/:10.1016/j.aos.2012.08.002.

Jørgensen, B., and M. Messner. 2009. Management Control in New Product Development: The Dynamics of Managing Flexibility and Efficiency. Journal of Management Accounting Research 21 (1): 99124, https://doi.org/:10.2308/jmar.2009.21.1.99. 
Kilfoyle, E., A. J. Richardson, and L. D. MacDonald. 2013. Vernacular accountings: Bridging the cognitive and the social in the analysis of employee-generated accounting systems. Accounting, Organizations and Society 38 (5): 382-96, https://doi.org/:10.1016/j.aos.2013.08.001.

Korsgaard, M. A., H. J. Sapienza, and D. M. Schweiger. 2002. Beaten Before Begun: The Role of Procedural Justice in Planning Change. Journal of Management 28 (4): 497-516, https://doi.org/:10.1177/014920630202800402.

Krug, J. A. 2003. Executive Turnover in Acquired Firms: An Analysis of Resource-Based Theory and the Upper Echelons Perspective. Journal of Management \& Governance 7 (2): 117-43, https://doi.org/:10.1023/A:1023607012229.

Lincoln, Y., and E. Guba. 2000. The only generalization is: there is no generalization. In Case study method : key issues, key texts, edited by R. Gomm, M. Hammersley and P. Foster, 27-44. London, England: SAGE.

Long, C. P. 2018. To control and build trust: How managers use organizational controls and trust-building activities to motivate subordinate cooperation. Accounting, Organizations and Society 70: 69-91, https://doi.org/:10.1016/j.aos.2018.05.006.

Lukka, K., and S. Modell. 2010. Validation in interpretive management accounting research. Accounting, Organizations and Society 35 (4): 462-77, https://doi.org/:10.1016/j.aos.2009.10.004.

Mahama, H., and M. M. Cheng. 2013. The Effect of Managers' Enabling Perceptions on Costing System Use, Psychological Empowerment, and Task Performance. Behavioral Research in Accounting 25 (1): 89-114, https://doi.org/:10.2308/bria-50333.

Malmi, T., and D. A. Brown. 2008. Management control systems as a package-Opportunities, challenges and research directions. Management Control Systems as a Package 19 (4): 287-300, https://doi.org/:10.1016/i.mar.2008.09.003.

Marks, M. L., and P. H. Mirvis. 1985. Merger Syndrome: Stress and Uncertainty (Part 1). Mergers and Acquisitions 20 (2): 50.

Marks, M. L., and P. H. Mirvis. 1997. Revisiting the Merger Syndrome: Dealing with Stress. Mergers and Acquisitions 31 (6): 21-7.

Markus, M. L. 1983. Power, politics, and MIS implementation. Commun. ACM 26 (6): 430-44, https://doi.org/:10.1145/358141.358148. 
Mayer, R. C., J. H. Davis, and F. D. Schoorman. 1995. An Integrative Model Of Organizational Trust. The Academy of Management Review 20 (3): 709-34, https://doi.org/:10.5465/amr.1995.9508080335.

Miles, M. B., and A. M. Huberman. 1994. Qualitative data analysis: an expanded sourcebook. 2nd ed. Thousand Oaks, CA: Sage.

Miller, C. C., L. B. Cardinal, and W. H. Glick. 1997. Retrospective Reports in Organizational Research: a Reexamination of Recent Evidence. Academy of Management Journal 40 (1): 189-204, https://doi.org/:10.2307/257026.

Mundy, J. 2010. Creating dynamic tensions through a balanced use of management control systems. Accounting, Organizations and Society 35 (5): 499-523, https://doi.org/:10.1016/i.aos.2009.10.005.

Otley, D. T. 1980. The contingency theory of management accounting: Achievement and prognosis. Accounting, Organizations and Society 5 (4): 413-28, https://doi.org/:10.1016/03613682(80)90040-9.

Roberts, J. 1990. Strategy and accounting in a U.K. conglomerate. Accounting, Organizations and Society 15 (1-2): 107-26, https://doi.org/:10.1016/0361-3682(90)90017-0.

Rousseau, D. M., S. B. Sitkin, R. S. Burt, and C. Camerer. 1998. Not So Different After All: A CrossDiscipline View Of Trust. The Academy of Management Review 23 (3): 393-404, https://doi.org/:10.5465/amr.1998.926617.

Sandelin, M. 2008. Operation of management control practices as a package-A case study on control system variety in a growth firm context. Management Control Systems as a Package 19 (4): $324-$ 43, https://doi.org/:10.1016/j.mar.2008.08.002.

Schweiger, D. M., and A. S. Denisi. 1991. Communication with Employees Following a Merger: A Longitudinal Field Experiment. The Academy of Management Journal 34 (1): 110-35, https://doi.org/:10.5465/256304.

Simons, R. 2005. Levers of organization design : how managers use accountability systems for greater performance and commitment. Boston, MA: Harvard Business School Press.

Sinkovics, R. R., S. Zagelmeyer, and V. Kusstatscher. 2011. Between merger and syndrome: The intermediary role of emotions in four cross-border M\&As. International Business Review 20 (1): 27-47, https://doi.org/:10.1016/j.ibusrev.2010.05.002. 
Taipaleenmäki, J. 2013. Absence and Variant Modes of Presence of Management Accounting in New Product Development - Theoretical Refinement and Some Empirical Evidence. European Accounting Review: 1-52, https://doi.org/:10.1080/09638180.2013.811065.

Tessier, S. 2012. From Field Notes, to Transcripts, to Tape Recordings: Evolution or Combination? International Journal of Qualitative Methods 11 (4): 446-60.

Tessier, S., and D. Otley. 2012. A conceptual development of Simons' Levers of Control framework. Management Accounting Research 23 (3): 171-85, https://doi.org/:10.1016/i.mar.2012.04.003.

Tomkins, C. 2001. Interdependencies, trust and information in relationships, alliances and networks. Accounting, Organizations and Society 26 (2): 161-91, https://doi.org/:10.1016/S03613682(00)00018-0.

Vélez, M. L., J. M. Sánchez, and C. Álvarez-Dardet. 2008. Management control systems as interorganizational trust builders in evolving relationships: Evidence from a longitudinal case study. Accounting, Organizations and Society 33 (7): 968-94, https://doi.org/:10.1016/i.aos.2008.02.006.

Wouters, M., and D. Roijmans. 2011. Using Prototypes to Induce Experimentation and Knowledge Integration in the Development of Enabling Accounting Information. Contemporary Accounting Research 28 (2): 708-36, https://doi.org/:10.1111/j.1911-3846.2010.01055.x.

Wouters, M., and C. Wilderom. 2008. Developing performance-measurement systems as enabling formalization: A longitudinal field study of a logistics department. Accounting, Organizations and Society 33 (4-5): 488-516, https://doi.org/:10.1016/j.aos.2007.05.002. 


\section{Appendix 1}

Interviews at "Finski"

\begin{tabular}{|c|c|c|c|}
\hline No. & Date & Interviewee position & Duration \\
\hline 1 & 15th Oct 2013 & Manager, Business Operations & $1 \mathrm{~h} 51 \mathrm{~min}$ \\
\hline 2 & 21st Oct 2013 & Accountant 1 & $58 \mathrm{~min}$ \\
\hline 3 & 21st Oct 2013 & Accountant 2 & $49 \mathrm{~min}$ \\
\hline 4 & 23rd Oct 2013 & Manager, After-Sales Services & $1 \mathrm{~h} 23 \mathrm{~min}$ \\
\hline 5 & 23rd Oct 2013 & Coordinator, Sales Support & $1 \mathrm{~h} 2 \mathrm{~min}$ \\
\hline 6 & 29th Oct 2013 & Manager Project 1 & $1 \mathrm{~h} 18 \mathrm{~min}$ \\
\hline 7 & 29th Oct 2013 & Designer, Chief Shop Steward & $1 \mathrm{~h} 37 \mathrm{~min}$ \\
\hline 8 & 30th Oct 2013 & Director, R\&D (former VP) & $1 \mathrm{~h} 26 \mathrm{~min}$ \\
\hline 9 & 30th Oct 2013 & Manager, Business Administration & $1 \mathrm{~h} 17 \mathrm{~min}$ \\
\hline 10 & 5th Nov 2013 & Manager, Sales 1 & $1 \mathrm{~h} 34 \mathrm{~min}$ \\
\hline 11 & 5th Nov 2013 & Manager, IT & $1 \mathrm{~h} 32 \mathrm{~min}$ \\
\hline 12 & 15th Nov 2013 & Manager Project 2 & $1 \mathrm{~h} 21 \mathrm{~min}$ \\
\hline 13 & 15th Nov 2013 & Assistant, HR \& Admin & $52 \mathrm{~min}$ \\
\hline 14 & 20th Nov 2013 & Director, Business Division (former VP) & $1 \mathrm{~h} 24 \mathrm{~min}$ \\
\hline 15 & 20th Nov 2013 & Director, Finance (former VP) & $1 \mathrm{~h} 37 \mathrm{~min}$ \\
\hline 16 & 25th Nov 2013 & Director, Human Capital & $1 \mathrm{~h} 14 \mathrm{~min}$ \\
\hline 17 & 29th Nov 2013 & Manager, Sales 2 & $2 \mathrm{~h} 20 \mathrm{~min}$ \\
\hline 18 & 16th Jan 2014 & Director, Operations (former VP) & $2 \mathrm{~h} 8 \mathrm{~min}$ \\
\hline
\end{tabular}

Interviews at "Gretzky"

\begin{tabular}{llll} 
No. & Date & Interviewee position & Duration \\
\hline 19 & 12th Nov 2013 & Manager, Services EMEA (Europe, Middle-East and Africa) & $1 \mathrm{~h} 13 \mathrm{~min}$ \\
20 & 25th Feb 2014 & Analyst 1, ERP Configuration & $1 \mathrm{~h} 5 \mathrm{~min}$ \\
21 & 25th Feb 2014 & Analyst 2, ERP Configuration & $1 \mathrm{~h}$ \\
22 & 25th Feb 2014 & Director, Financial Reporting and Accounting & $58 \mathrm{~min}$ \\
23 & 26th Feb 2014 & Technician, International Accounting & $33 \mathrm{~min}$ \\
24 & 26th Feb 2014 & Accountant & $51 \mathrm{~min}$ \\
25 & 26th Feb 2014 & Manager, Corporate Purchasing & $36 \mathrm{~min}$ \\
26 & 26th Feb 2014 & Manager, IT & $45 \mathrm{~min}$ \\
27 & 27 th Feb 2014 & Analyst, Logistics & $48 \mathrm{~min}$ \\
28 & 27 th Feb 2014 & Analyst, Financial & $43 \mathrm{~min}$ \\
29 & 27th Feb 2014 & Coordinator, Inventory and Demo Equip. & $54 \mathrm{~min}$ \\
30 & 28th Feb 2014 & Director, Budget, Project and Support & $46 \mathrm{~min}$ \\
31 & 28th Feb 2014 & Analyst 3, ERP Configuration & $32 \mathrm{~min}$ \\
32 & 28th Feb 2014 & CFO (VP) & $49 \mathrm{~min}$ \\
\hline
\end{tabular}




\section{Appendix 2}

Archival documents obtained by the researchers and used for analysis. Documents were gathered between 2010 and 2014.

\section{Internal documents}

KPI reports (confidential)

Internal letters (confidential)

Documents concerning variable pay (confidential)

Presentations about performance measurement

Organizational charts

Presentations of segmented P\&L

Emails following interviews (sent to the researcher)

\section{Publicly available documents}

Mission statement

Annual reports 2009-2013

Financial disclosures

Presentations of acquisitions made by Gretzky (published information)

Book chapters describing Gretzky's NPD process

Newspaper articles about Finski acquisition by Gretzky 
Table 1. A processual framework to foster enabling perceptions

Table 1 summarizes our conceptual development on the factors that foster enabling perceptions throughout the process of adding new MCs, from the intention behind their implementation, to their development and daily use. The table also provides empirical examples from this study to support our conceptual development.

\begin{tabular}{|c|c|c|}
\hline $\begin{array}{l}\text { PHASES OF MCS } \\
\text { IMPLEMENTATION }\end{array}$ & CONCEPTUAL DEVELOPMENT & EMPIRICAL EXAMPLES FROM THIS STUDY \\
\hline $\begin{array}{l}\text { MANAGERIAL } \\
\text { INTENTIONS }\end{array}$ & $\begin{array}{l}\text { Managerial intentions based on trust support enabling perceptions } \\
\text { - Implementing controls to support employees so they perform their } \\
\text { work tasks better } \\
\text { - Implementing controls to comply with exogenous circumstances, } \\
\text { including SOX, IFRS, M\&A, ERP system, etc. }\end{array}$ & $\begin{array}{l}\text { Gretzky managers trust Finski employees, but: } \\
\text { - Want to keep operations efficient } \\
\text { - need to integrate Finski into their MC system } \\
\text { - Have to comply with SOX and IFRS } \\
\text { - use ERP system to implement required SOX controls }\end{array}$ \\
\hline $\begin{array}{l}\text { DEVELOPMENT } \\
\text { PROCESS }\end{array}$ & $\begin{array}{l}\text { A development process that fosters trust supports enabling } \\
\text { perceptions } \\
\text { - Managers fostering employees' trust in the new controls: } \\
\text { - Through experimentation } \\
\text { - By explaining managerial intentions } \\
\text { - Managers demonstrating their trust in employees by: } \\
\text { - Allowing them to participate in the development process } \\
\text { - Capitalizing on their experience and knowledge } \\
\text { - Importing local procedures to the global organization } \\
\text { - Managers demonstrating their trustworthiness: } \\
\text { - Through trust-building activities }\end{array}$ & $\begin{array}{l}\text { Gretzky managers build trust by: } \\
\text { - Building personal relationships with subordinates } \\
\text { - Steering the integration process firmly and decisively } \\
\text { - Rationalizing implementation of MCs relating to SOX and ERP } \\
\text { - Restricting participation only with controls that need to be rigid for } \\
\text { exogenous reasons }\end{array}$ \\
\hline DAILY USE & $\begin{array}{l}\text { Controls that are usable on a daily basis support enabling perceptions } \\
\text { - Usability is enhanced by design features } \\
\text { - Design features require managers to trust employees } \\
\text { - Design features are not equally important to ensure usability if: } \\
\text { - Employees can rationalize the need for standardization and its } \\
\text { benefits } \\
\text { - Managers provide alternative ways of overcoming missing features. } \\
\text { This requires employees to trust managers }\end{array}$ & $\begin{array}{l}\text { Finski employees find the new MCs usable: } \\
\text { - Finski employees appreciate the benefits brought about by the MCs } \\
\text { - During meetings: Finski employees ask for repair and flexibility when } \\
\text { needed } \\
\text { - Information is given to Finski employees to provide global } \\
\text { transparency } \\
\text { - Positive relationships and mutual trust are maintained through } \\
\text { frequent meetings }\end{array}$ \\
\hline
\end{tabular}

a) Demonstrating competence (managers being knowledgeable), benevolence (managers caring about employees' welfare) and reliability (managers being dependable and predictable) (see Long 2018, 74)

b) Repair (fixing issues with MCs), internal transparency (understanding inner workings of MCs), global transparency (understanding where MCs fit into global processes), flexibility (having discretion over the use of MCs) (see Adler and Borys 1996, 70-4) 